The Ecology of Freshwater Molluscs.

By Robert T Dillon, Jr. Cambridge and New York: Cambridge University Press. $\$ 120.00$. xii +509 p; ill.; index. ISBN: 0-521-35210-X. 2000.

As the author unabashedly proclaims, this is an organismal book. Like its literature base, the volume mostly reviews intraspecific research or focuses on interspecific interactions involving mollusc communities, food, or predators. The book consists of 9 chapters: Introduction; Bivalve autecology; Gastropod autecology; Life history; Population dynamics and competition; Parasitism; Predation; Biogeography; and Communities. A useful summary is included in most chapters. Both bivalves and gastropods are discussed in Chapters 4 through 9, with frequent subdivisions by family and a heavier emphasis on snails. The book's strengths are its comprehensive review of autecology and population biology, a very readable, nearly error-free text, and an extensive, updated reference list (approximately 1200 citations). Taxonomy, anatomy, and general physiology are not covered except as related to ecology. Dillon adds to the molluscan review by sprinkling his own conceptual and statistical syntheses throughout the book, and introduces his gastropod life-history model.

Although I strongly recommend this book, it has clear shortcomings for some aquatic ecologists. For example, no significant mention is made of turbidity effects, quagga mussels, why carnivorous snails are generally absent from fresh waters, and previous molluscan syntheses. The volume would have been immeasurably improved by chapters on conservation biology and community/ecosystem ecology (e.g., benthic-pelagic coupling, nutrient/ energy cycling, and effects on other benthic species from pseudofeces and habitat "created" by molluscs). The total absence of photographs and drawings of species is regrettable. For example, Dillon describes bivalve reproductive mimicry as among "the greatest marvels of the natural world" ( $p 44$ ), but then fails to illustrate the mantle of one species that resembles a minnow (apparently attracting piscivorous fish as hosts for bivalve glochidia). His writing style, although generally good, is occasionally laid-back, as in the phrase, "[s]o to tie the whole project up with a red ribbon" ( $\mathrm{p} 70)$; this may charm some readers but distract others.

This book definitely belongs on shelves of all molluscan biologists and would interest many other benthic ecologists. I also recommend it as a library purchase to aid teaching of invertebrate zoology and various courses touching on aspects of aquatic ecology.

James H Thorp, Biology, Clarkson University, Potsdam, New York

\section{ENVIRONMENTAL SCIENCES}

Environmentalism for a New Millennium: The Challenge of Coevolution.

By Leslie Paul Thiele. Oxford and New York: Oxford University Press. $\$ 35.00$. xxviii +302 p; index. ISBN: 0-19-512410-3. 1999.

Biologists beware: this book is not about biological processes of coevolution. Do not expect accounts of coevolving plants, pests, or pathogens. Instead, expect to learn about environmentalism in the United States. The author, a political scientist, recognizes four waves of environmentalism and uses "coevolution" as a term for the goals of the fourth wave.

These four waves of environmentalism include conservation (mid-1800s to 1960s); containment (early 1980s); co-optation (1980s to early 1990s); and coevolution (the new millennium). During the first wave, national parks and wilderness areas were established. During the second wave, environmentalists sought to contain growth of human populations and industries. The third wave brought environmentalism into the mainstream of American culture where it was co-opted by various opposing political and economic factions. The fourth wave offers antidotes to conflict by advocating partnerships among environmentalists who strive for stable coexistence of humans and the rest of nature: "Fourth-wave environmentalism is grounded in the effort to integrate humankind into natural systems. The ultimate goal is a dynamic, shared existence-a coevolution" (p 31).

Four of the book's six chapters analyze components of the fourth wave of environmentalism: how to maintain human enterprise "sustainably"; the importance of planning for future generations of humans; environmental justice (e.g., globalism and environmentalism without racism, sexism, or classism); and concern for other species (e.g., biocentrism and environmental ethics). The book concludes with a warning about antienvironmental backlash, and an appeal for investment in environmental education.

This volume is about the environmental movement. So many environmental organizations are discussed that I found myself looking for an appendix or a table that would help me distinguish Defenders of Wildlife from the National Wildlife Federation, or EarthFirst! from Friends of the Earth. Although such a summary would have been helpful, this book will still be of value to anyone interested in the largely complementary agendas of different environmental organizations. This volume explains 